\title{
HRM practices and performance management in public service organizations in Bangladesh: An empirical study
}

\author{
Mohammad Aktaruzzaman Khan, Nazamul Hoque \\ and A. M. Shahabuddin \\ Department of Business Administration \\ International Islamic University Chittagong (IIUC), Bangladesh
}

\begin{abstract}
This paper assesses the effects of HRM practices on the management performance of public service organizations as public service is believed to safeguard the national property for allocating goods and services timely, and reasonably to the inhabitants of the country especially in a developing country like Bangladesh. The question circling whether the HR practices in public service are sincere for equal and equitable distribution of products and services effectively. In doing so, this study investigated the effectiveness of HR practices and methods on the performance management of public service. The study, through a mixed-method approach, conveniently surveyed a sample of 142 respondents and interview drawn from seven key informants of two Bangladesh Civil Service (BCS) cadre from Chittagong, the second-largest city of the country. The study shows the differences in the effects of HRM practices that employee training positively and commensurate compensation negatively predict employee performance, respectively, however, performance appraisal feedback is not a significant predictor. The study drawn the implications for HRM practices in BCS organization and encouraged future scholars to further examine these differences.
\end{abstract}

Keywords Bangladesh, HR practice, Performance management, Public service, Resource base theory

Paper type Research paper

\section{Introduction}

The Public Service is responsible for keeping the national property and for providing public goods or services timely, and reasonably to the inhabitants of the country. In doing so, the public service is divided into various Ministries, Divisions, and regional/field-level administrative wings, and other specialized bodies. In Bangladesh, as perceived by the common mass, some of the goods and services provided by the Government can also be obtained at a higher cost from the private sector. The service delivery, however, appears to

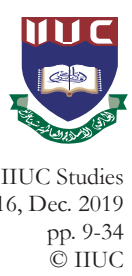

ISSN 1813-7733 
more complex than is commonly understood in the western set up (Roch \& Poister, 2006) and also falls short of expectations both in developed and developing countries (Amani, 2013; Andaleeb, 2001; Gould-Williams, 2003; Khalid, Rehman, \& Ilyas, 2013). There is a scarcity or little research conducted on to what extent citizens' expectations about the quality of public services as well as private-level services (Uddin, Ali, \& Khan, 2018) are satisfied (Roch \& Poister, 2006). In the health sector, patients' perceptions seem to have been largely ignored by service providers in developing countries like Bangladesh (Andaleeb, 2001). So, there has been criticism by the electorates who are the taxpayers that raise revenue for the Government to meet its obligations, on the quality of service delivery mainly due to practices and attitude of public servants. Government has, however, exonerated its officials citing limited fiscal resources to meet all needs adequately. The general assessment is that the expectations of the people are not being met. There are a plethora of studies that prompted whether HRM practices could bring beneficial effects to public organizations (Brown, 2004; Burke, Noblet, \& Cooper, 2013). Thus, in the following section, the study has highlighted the HRM practices and its effects on the public organization, theoretically as well as empirically.

\subsection{Human resource management practices}

The Michigan and Guest Models of HRM rely heavily on the Resource Based View (RBV) theory on which this study is anchored. The theory emphasizes a critical approach to the organizations in building internal capabilities within its internal environment, and identifies the value creating potential of internal resources (Boxall \& Purcell, 2011). This is necessary in order to assess the influence that internal resources have on the organization's competitive advantage. HRM practice has indeed helped organizations achieve competitive advantage. Other researchers who are the proponent of RBV, have acknowledged that competitive advantage can be developed in such a way that is not easily imitated or difficult for others to imitate (Penrose 1995; Barney, 1991: 99-120).

In fact, HRM practice has been noted to directly or indirectly affect a number of variables in organizations, the Public Service included. This study focuses on best HR practices and how they affect performance management in the Public Service. It would, therefore, be useful to examine how HRM practices affect variables in the workplace, in addition to creating competitive advantage. Tzafrir, Harel, Yehuda, and Dolan (2004) alluded that HRM practices impact on employee-employer relationships as these could be improved if the organization implements effective HRM practices. A 
systematic cross-sectional investigation of the effects of HRM practices on the public organization such as BCS of Bangladesh has been undertaken very few attempt yet. It is due to some extent sensitivity to the said issues or conservative behavior to share their opinion with public. In this respect, a mixed method approach is a powerful intervention to aggregate previous research outputs with the empirical findings of this study undertaken to estimate a general understanding.

This study seeks to investigate the management of performance in the Public Service in Bangladesh. However, in applying the best practices of human resource management an evaluation should be undertaken to determine if the employees are performing at the level expected and also how the HRM practices such as training (Jacobs, 2009), performance appraisal feedback (Rubel \& Kee, 2014), and compensation management (Armstrong \& Murlis, 2007; Juhdi, Pa’wan, \& Hansaram, 2013; Nadiri \& Tanova, 2010), influence the employee skills and motivation to perform in the organizational level. Best HRM practices would be expected to impact on employee skill through the acquisition of quality and right caliber of staff and the continuous development of their skills that will then be expected to contribute to consistency and sustainability in performance levels. Such relationships between HRM practices and organizational performance in private sectors were pertinent in the past (Rondeau \& Wagar, 2001), and also found significant in recent years (Budhwar, Chand, \& Katou, 2007; Joseph \& Dai, 2009; Mostafa \& Gould-Williams, 2014; Nayaab, Hamid, Naseer, \& Iqbal, 2011; Osman, Ho, \& Carmen Galang, 2011). While the results of the previous researches were based on a private sector business activity, this state of affairs might also be true for public service organizations. Therefore, the authors of this study feel it is time-worthy and important in assessing how well the public service in developing country like Bangladesh is doing.

\subsection{Performance management in public service}

Generally, employees in the private sectors are oriented towards producing goods and services that result in increased profit for the organization. In the Public Service, employees see themselves as contributing to an efficient and effective cadre that reduces costs in provision of services to the public, in the most economical manner possible. This however, may not be easily accomplished as a study in the United Kingdom (CIMA, 2010:1) established that the complexity and diversity of public sector organizations like the public service complicate service delivery due to the complex nature and variety of end user demands, the options available for service delivery and lack of concern and pressure for profit, often leads to poor performance. 


\section{IIUC Studies, 16}

Whereas, another UK-based study conducted demonstrated that HR practices are powerful predictors of organizational performance (Gould-Williams, 2003). In Malaysia, a study (Iyer, 2011:1) established a similar pattern of "poorly performing public service as a consequence of lack of accountability in service delivery, disparity in policy planning and inadequate coordination across public agencies, especially at ministerial level." In a developing country perspective two study conducted in Bahrain and Pakistan in 2013 are noteworthy here. Amani (Amani, 2013) in Bahrain found significant impact between HR practices (such as recruitment and selection, job definition, career planning, training, employee appraisal, employee participation and compensation) and employee performance. Whereas, Khalid et al. (2013) employed an empirical study with 32-items survey instrument among 120 managers of Lahore-based eleven public organizations of Pakistan that demonstrated unsteady performance. The later study suggested to develop indigenous HRM practices to inculcate with modern HR practices in order to escalate employee performance.

In its very basic definition, Performance Management is just a process of assessing what needs to be done, and how it is done. Critically, it could be said to be a process that involves planning, monitoring, evaluation and rewarding with the sole purpose of aligning the organizations level performance to the overall strategy. From this perspective, performance management should be seen as a framework that synthesizes financial and operational information into one single framework. The KPI Institute (2013:30) defines Performance Management as - "An on-going, and systematic approach and process for evaluating employees' performance and group performance, and aligning this evaluation to the organization's strategy, the unit strategy, the mission and the vision of the organization for the sake of continuous improvement and increasing individual's and groups' productivity and, therefore the productivity of the entire organization."

It is evident from the above definition that the desire is to continuously seek to improve and increase performance of individuals which ultimately contributes to the group and the organization itself. According to Khatri (1999:516-529), people are one of the most important factors providing flexibility and adaptability to organizations. Rundle (1997:3-24) argues that one needs to bear in mind that people (managers) not the firm, are the adaptive mechanism in determining how the firms will respond to the competitive environment. Several scholars have noted that managing people is more difficult than managing technology or capital (Barney, 1991: 99-120; Lado \& Wilson, 1994:699-727). However, these firms that have learnt to manage their human resources well would have an edge over others for a 
long time to come because acquiring and deploying human resources effectively is cumbersome and takes much longer (Wright, MacMahan, \& MacWilliams, 1994). The effective management of human resources requires sound HRM systems. Storey (Storey, 1995:29) defines HRM as - "A distinctive approach to employment management which seeks to obtain competitive advantage through the deployment of a highly committed and skilled workforce using an array of techniques". HRM, therefore, help firms improve the organizational behavior in the areas of loyalty, flexibility, competence, and commitment with a view to improving staff performance. In order to develop a sound HRM system the organization should have effective HR practices. "The HR practices refer to organizational activities directed at managing the pool of human resources and ensuring that resources are employed towards the fulfillment of organizational goals" (Schuler \& Jackson, 1987: 207-219; Schuler \& MacMillan, 1984: 241-255; Wright \& Snell, 1991: 203-225). Paauwe stated that HRM as an enabler, 'enabling' implies that the HR practices' main goal is the development of a workforce with a sufficient degree of flexibility/adaptability to implement a range of organizational goals (Paauwe, 2004, 2009). So, the above discussion prompted the authors to think that they are in need of studies with the right research design that is able to investigate the link between HR practices and performance. This conceptual understanding is also in line with some classic works of several researchers (Guest, Michie, Conway, \& Sheehan, 2003; van Veldhoven, 2005; Wright, Gardner, Moynihan, \& Allen, 2005). Hence, in doing so, the study proceeds with the following research objectives to investigate:

\section{Research questions and objectives}

Hence, the authors seek to investigate the following questions as - (1) what HR practices are employed in managing performance in the Public Service? And (2) what are the effects of these HR practices on managing performance? In line with the questions set for this study the two objectives have been employed to test the research questions as;

Objective One: To identify the HR practices and methods used in the Public Service to manage performance.

Objective Two: To determine the effectiveness of the Performance Management tools for measuring performance.

\section{Theoretical underpinnings}

In this study focus is on human resource practices applied in the Public Service as they ultimately may affect performance management. In managing 
performance, the critical components in the performance matrix, the resources employed or expended will have to be assessed against the objective attained. The background to this study will, therefore, be anchored the Resource Based View (RBV) of organizations while also looking at the Balanced Scorecard (BSC) to evaluate the internal capabilities of the public service. Boxall and Purcell (2011) have suggested that this approach, 'facilitates the analysis of the public service internal environment and explore the value-creating potential of the internal resources and how they can make the public service achieve competitive advantage and cost reduction in service delivery'. The public service regards its employees according to their contribution to the attainment of the objectives of the public service as well as value addition and ability of the individual.

\section{Methodology}

In order to carry this study, a plan of the proposed research work was made. For formulating a suitable design, several considerations were taken into account. A research design is "An overall framework of a research that explains the direction and method to be used in the study to gather the information needed, either from primary or secondary sources" (Khan \& Ali, 2014, 2015; Malhotra, 2007) or the process of arriving at dependable solutions to problems through a planned systematic collection, analysis and interpretation of data (Orodho \& Kombo, 2002:2).

In this study both quantitative and qualitative approaches have been used. The quantitative approach has the characteristic of measuring objective facts using variables where data is separated from theory, statistically analyzed and emphasizes reliability. The quantitative approach has been used to empirically investigate the phenomenon using statistical techniques such as tables, charts and other statistical measurements such as multiple regressions to prove cause-effect relationships between independent variables - HR practices - like employee training, employee performance appraisal feedback, and employee compensation and benefits, and dependent variable performance management of BCS organization. This study has used a combination of both 'exploratory' and 'descriptive or explanatory/causal' approaches to gain a better understanding of the phenomenon under study as "exploratory studies are common for areas that are under researched and require a theoretical framework for subsequent studies" (Babbie, 2010: 92-113; Khan \& Ali, 2014, 2015) while "descriptive research on the other hand aims at generating descriptions of the observed phenomenon which in turn best describes the situation in greater detail" (Yin, 2012). 


\subsection{Subject and site}

This study investigated the HR practices with regard to performance management in the Public Service. The study, it is hoped, will inter alia provide better understanding and assessment of the quality of service in the Public Service and reasons for such performance levels. The study has been limited and focused on two key cadre services of the Government such as health and education services in Chittagong city areas, the second largest city of the country (Khan \& Jahur, 2007). The impact of human resource practices on performance management though widely researched worldwide, have nevertheless received little attention in Bangladesh, hence, this study still pertinent to the discussion especially in the Public Service (Hussain \& Utsho, 2018). The scarcity of study on Public Service organization especially on management effectiveness, is mainly, due to over sensitivity to information or opinion sharing with the public which falls within the purview of violation of Public Service Acts.

\subsection{Data collection techniques}

In this study, the purpose of which was to investigate the HR practices on Performance Management in Bangladesh Civil Service (BCS) officers, an exploratory research was used in combination with descriptive research which Mason and Bramble (1978: 51) defined "as a presentation of a broad range of activities that have in common, the purpose of describing situations or phenomenon". For qualitative purpose an unstructured interview protocol was employed to figure out the HR practices in the sample cadre services. The snowball sampling techniques was used to select the sample for unstructured interviews. Due to unwillingness of the BCS officials to disclose their snowball-sampled opinion, the authors had to give their personal commitment to maintain confidentiality. This snowball technique was economical and useful in locating rare informants of the population (Morgan, Ataie, Carder, \& Hoffman, 2013). Subsequently, the findings of the qualitative intervention help the researchers to form the quantitative part.

The study then employed a survey through a structured questionnaire consisting of 31 (thirty one) items ranging from HR practices (such as employee training and development programs, compensation and benefits, performance appraisal and feedback) to management of performance and the results were then tested using SPSS (version 21). The sample drawn conveniently as it not only helped minimize bias but also offered access to the body of probability theory, thereby providing the basis for estimating the characteristics of the population as well as the accuracy of the samples. The questions were formed on the 5-point Likert scale $(1=$ strongly disagree to $5=$ strongly agree) which according to Zikmund, Babin, Carr, and Griffin 
(2013: 316) "is a measure of attitudes designed to allow respondents to rate how strongly they agree or disagree with carefully constructed statements, ranging from very positive to very negative attitudes towards some object."

\subsection{Sample descriptions}

In this study, two hundred potential respondents were scheduled to be interviewed using the questionnaire indicated in this research. However, only one hundred and forty two (142) self-administered questionnaires were successfully taken into account after dropping the incomplete ones. Further, seven (7) senior executives/directors were interviewed using the un-structured questionnaire.

Table 1: Descriptive statistics of the survey respondents

\begin{tabular}{|c|c|c|c|c|c|c|}
\hline & \multicolumn{6}{|c|}{ Education level of employees } \\
\hline & & Higher Diploma & Graduation & Masters & $\mathrm{PhD}$ & Total \\
\hline \multirow[t]{2}{*}{ Gender } & Male & 8 & 74 & 18 & 2 & 102 \\
\hline & Female & 6 & 24 & 10 & -- & 40 \\
\hline Total & & 14 & 98 & 28 & 02 & 142 \\
\hline \multirow[t]{4}{*}{ Cadre Name } & & Education & Health & & & \\
\hline & Male & 40 & 52 & & & 92 \\
\hline & Female & 22 & 28 & & & 50 \\
\hline & & Married & Single & Widow & Divorced & \\
\hline Marital & Male & 80 & 10 & 4 & 8 & 102 \\
\hline status & Female & 32 & 5 & 1 & 2 & 40 \\
\hline
\end{tabular}

From the profile of the respondents it can be noted that the total number of employees in the sample is one hundred and forty two (142) comprising one hundred and two (102) men and forty (40) women. Of the 102 males sampled 8 attained higher diploma education while 74 have graduate qualification with 18 master degree and $2 \mathrm{PhD}$. With regard to the forty women sampled, 6 have higher diploma, 24 have graduate qualifications while only ten female candidate had post graduate qualifications. For occupational statistics of all the employees interviewed who constitutes this sample 62 are from the education cadre while 80 drawn from health cadre service. The above Table-1 also noted that 112 employees are married, 15 employees are single, and 5 employees are widows while 10 are divorced. The respondents are within the age bracket of 28 to 55 .

\section{Results}

Having satisfied all the assumptions such as test of normality, Normal P-P Plot, Scatterplot for the model, the researchers then proceeded to use the 
regression analysis to obtain the coefficient of the estimated regression equation. The results of the regression analysis are as indicated in Table 2 below:

Table 2: Estimated Regression Equations

\begin{tabular}{|c|c|c|c|c|c|c|c|}
\hline \multirow[b]{3}{*}{ Model } & \multicolumn{5}{|c|}{ Co-efficients ${ }^{a}$} & \multirow{2}{*}{\multicolumn{2}{|c|}{$\begin{array}{l}\text { Collinearity } \\
\text { Statistics }\end{array}$}} \\
\hline & \multicolumn{2}{|c|}{$\begin{array}{c}\text { Unstandardized } \\
\text { Coefficients }\end{array}$} & \multicolumn{2}{|c|}{$\begin{array}{l}\text { Standardized } \\
\text { Coefficients }\end{array}$} & & & \\
\hline & B & Std. Error & Beta & $\mathrm{t}$ & Sig. & Tolerance & VIF \\
\hline (Constant) & 2.605 & .329 & & 7.721 & .000 & & \\
\hline Employee training & .367 & .065 & .328 & 5.766 & .000 & .954 & 1.168 \\
\hline Performance appraisal feedback & .092 & .047 & .117 & 1.872 & .065 & .845 & 1.289 \\
\hline Employee compensation & -.108 & .049 & -.140 & -2.295 & .024 & .878 & 1.299 \\
\hline
\end{tabular}

a. Dependent Variable: Performance management (of organization)

From the results of the estimated regression equations above, it is found that the $y$ intercept ( $\beta$ o - coefficient) has a value of 2.605. The positive sign on the coefficient implies that the probability of performance on average increases by 2.605 when the employees training, employee performance appraisal and employee compensation are set to zero. The coefficient of training $(\beta 1)$ is 0.367 , implying that when employee performance appraisal and employee compensation remain unchanged, a unit increase in the employee's training on average corresponds to an increase of 0.367 in the probability of performance. The coefficient for employee performance appraisal feedback $(\beta 2)$ is 0.092 . This implies that when employee training and employee compensation remain unchanged, a unit increase in the employee performance appraisal feedback would on average correspond to 0.092 increase in the probability of performance that meets expectations of the job. The coefficient for employee compensation ( $\beta 3)$ is -.108. This means that on the average a unit increases in employee compensation would correspond to -.108 decrease in the probability of performance while holding other variables in the model constant. For the complete diagnostics, the model summary is presented in Table 3 below;

Table 3: Model Summary

\begin{tabular}{lccccc}
\hline Model & $\mathrm{R}$ & R Square & Adjusted R Square & Std. Error of theEstimate Durbin-Watson \\
\hline 1 & $.489^{\mathrm{a}}$ & .250 & .243 & .856 & 1.566 \\
\hline
\end{tabular}

a. Predictors: (Constant), Employee training, Performance appraisal feedback, Employee compensation

b. Dependent Variable: Performance management (of organization)

Table-3 demonstrates the model summary. From the results in the model summary above, multiple correlation co-efficient $(\mathrm{R}=.489)$ indicates that there is a positive linear relationship between the dependent variable's probability of performance that meet expectations of the job and the independent variables such as employee training, employee performance appraisal feedback and employee compensation. 
The multiple coefficient of determination $\mathrm{R}^{2}(\mathrm{R}$ Square $=.250)$ suggest that the independent variables as stated above explained about $25 \%$ of the variance in performance management of the organization. This value implies that 25 percent of the variation in performance management of BCS organization (y) can be jointly explained by the predictor variables employee training, employee performance appraisal feedback and commensurate compensation of the employees. The power of the test, the adjusted $R^{2}(R$ Square $=243$ ) reflects the model's Goodness of Fit for the population.

Table 4: ANOVA $^{\mathrm{b}}$

\begin{tabular}{llccccc}
\hline Model & & Sum of Squares & Df & Mean Square & F & Sig. \\
\hline 1 & Regression & 32.889 & 4 & 10.963 & 14.686 & $.000^{a}$ \\
& Residual & 178.566 & 256 & .703 & & \\
& Total & 211.455 & 260 & & & \\
\hline
\end{tabular}

a. Predictors: (Constant), Employee training, Performance appraisal feedback, Employee compensation

b. Dependent Variable: Performance management (of organization)

4.1. Significance of the model

The ANOVA Table-4 above represents that the value for the F-test (sig) is .000 . At the significance level of 0.05 the P-value (.000) is less than 0.05 . The test result is significant and hence the researchers reject the Ho and concluded that there is sufficient evidence to suggest that at least one of the coefficients is significantly different from zero $(\neq 0)$.

\subsection{Significance of individual coefficients}

Hence, the researchers conclude that the coefficient for employee training program is significant ( $\mathrm{P}$-value of .000 is $<.05$ ) in predicting the performance management of BCS organization that meets the expectations of the job. Secondly, the coefficient for employee performance feedback is insignificant (P-value of .065 is not less than .05), and finally, coefficient for commensurate employee compensation is negatively significant (P-value of .024 is less than .05). The evidence suggest that the coefficient for commensurate employee compensation is significant in analyzing the probability of employee performance which meets the expectations of the job. It is noted that all the Variance Inflation Factors (VIF) in the Table for coefficients - 1.168, 1.289 and 1.299 are all less than 5. From this evidence, the researchers of this study conclude that multicollinearity is not a serious factor in this model. This study, therefore, it can be said that employee training (as depicted for the suitability of the job) and commensurate employee compensation predict the employee performance, however, employee performance appraisal feedback is not significant predictor.

In order to measure the normality assumptions there are several inferential statistical techniques are available. Out of them, Shapiro-Wilk test 
was employed for testing the variables and found that the data are correlated and normally distributed. The statistics for the variables were all greater than .05 and con be concluded that are normally distributed. For further confirmation, the boxplots also were used for examination and found within the expected range of distribution.

\section{Discussion}

This mixed method study, through survey and interviews, revealed several important findings that contributed to broadening our understanding of the HR practices and methods used by BCS organization and their impact on performance management. In the following sections, discussions will follow the two objectives set for this research.

5.1. Objective One (RO1): Identifying the HR practices and methods used in the Bangladesh Civil Service (BCS) to manage performance.

Through the intervention of this study, a number of HR practices and methods being used in managing performance have been highlighted. In Bangladesh Civil Service, the major activities that drive organizational performance management were identified as follows:

\subsubsection{Managing employee and organizational performance}

The mentioned activities above refer to the overall performance of a Government entity such as a Ministry or Division/Department. Using the same principle of accountability, and review of development and work plans for the year, individual employees in the Public Service could and are made accountable for their activities and actions. This will surely lead to an assessment of meeting the expectations of the employer or superior authority.

In Bangladesh for instance, the development of the Annual Confidential Report (ACR), a conventional performance appraisal instrument help the Public Service account for individual employee effort and performance towards the set objectives. However, now-a-days the modern and diverse workforce comprises employees who want to feel valued and treated with respect and to that extent, be given task and some freedom and authority to undertake it. And more diversified appraisal tool like $360^{\circ}$ performance appraisal (Khan \& Ali, 2014) can also be implemented for significance result.

\subsubsection{Performance evaluation and feedback}

The performance management monitoring and evaluation system play a cardinal role in ensuring the prudent utilization of resources availed to the Public Service and consequently, to the individual employees. Though, 
performance management as one of the important HR practices found to have predicted positive effects on private organizations (Nayaab et al., 2011; Osman et al., 2011) as well as public organizations in studies (Barney, 1995), however, the general public aired their concerns on the poor service delivery by the Public Service. Our study delineates that performance feedback does not significantly predict $(\beta=0.092, \mathrm{p}>.05)$ the organizational performance which is contrary to the previous studies (Gould-Williams, 2003; Paauwe, 2009). If we accept this finding at face value then it appears that it does not contribute greater effort. Another view, there might be a disjunction between appraisal feedback tool and organizational performance which demands more investigation into alternative tools and research. The public should receive timely feedback on services through their representatives in the government agencies. Lack of effective and regular assessment of tool for workers in order to provide adjust and equitable remunerations was seen as one of the reasons for brain drain among education service holders also for choosing and/or going developing countries to neighboring/developed countries for physical treatment every year (Dodani \& LaPorte, 2005; Lusale, 2007).

\subsubsection{Compensation and benefits}

The Ministries are responsible for the design and implementation of appropriate Performance Appraisal Systems (PAS) procedures and structures, and monitoring their effectiveness for efficient performance of the Public Service. PAS is intended to facilitate the attainment and optimization of both individual and organizational capabilities in the Public Service in order to achieve and sustain efficiency in the delivery of Public Services. According to one senior director of management development division under public service, it is important for the agencies to work hard so that the expectations of both the employers and employees are harmonized in terms of what Public duty is expected to be performed and at what cost to Government, and what benefit will the performance of such a duty bring to the individual employee in terms of job satisfaction relative to the work conditions, type of work and the related rewards for the effort expended. The official added to ensure that appropriate job evaluations are conducted and that appropriate remuneration packages that respect and reflect equity are designed and implemented. However, consultation to the present survey produced the answer that employee commensurate compensation is negatively significant $((\beta=-0.108, \mathrm{p}<.05)$ which is contrary to a strand of researches conducted on the relationship between compensation as a dimension of HRM and lowering the turnover intention (Juhdi et al, 2013; 
Nadiri \& Tanova, 2010) and organizational performance (Armstrong \& Murlis, 2007; Hoque, Awang, Siddiqui, \& Sabiu, 2018). The negative association suggest that greater emphasis on perceived compensation practices provides a close attachment of employees with their organization in Bangladesh context will surely lower the turnover intention or brain drain. It is also statistically perceived by general public that "Bangladeshi education workers and civil servants continue to be the least paid in the South-Asian region." This statement is consistent with that of one director who attributed brain drain to inadequate remuneration.

\subsubsection{Training and development}

It is expected that this reform in the Public Service will reinvigorate the spirit of hard work as employees will see links between their performance, career development and promotion as elaborated in their PAS which has refocused individual or personal development of employees as being essential to service delivery. The Bangladesh Public Administration Training Centre (BPATC) is the main staff training center for civil servants which is the main driver of routine and traditional way of imparting training for the public service organization (Jacobs, 2009). In course of time the training facilities and mechanism have substantially been changed which is well manifested in the results of this research also in line with the several recent studies (Khalid, Rehman, \& Ilyas, 2014; Muchhal, 2014). It is, partially, due to the fund provided by the World bodies such as UNDP, ADB or could be modernization of organizational process.

\subsubsection{Recruitment, selection and placement}

The Public Service in Bangladesh has a system of managing performance of employees. Further, according to one senior educationist, there is a considerable evidence available in the research to the effect that though the Bangladesh Public Service Commission (PSC) adopts appropriate practices in recruitment and selection of employees so that the right candidates are placed in the right jobs needed to deliver a Public Service, but there is existence of nepotism which is spoken by some senior government representatives on different occasion that appeared in newspapers as "impasse in the Ministries due to inefficient office bearer." Lack of proper practice, corruption, and political influence also prominent in health service in rural Bangladesh (Joarder, Rawal, Ahmed, Uddin, \& Evan, 2018), which put the performance of BCS organization in question. Although, the modalities for entry and qualifications may differ from one person, department or ministry to the other, it will be noted that the responsible 
Public Service Commission undertakes the nationwide recruitment process in three distinct phases on behalf of client Cadre Service or Departments.

\subsubsection{Leadership}

A positive management philosophy is not only intellectually and psychologically enriching but also helps employees of diverse cultural backgrounds to learn, accept and accommodate each other's differences yet harness these different and divergent skills and talents to create a well-balanced and professional talent pool to move the organization forward. Evidence on the Ministry of Health attributed poor working as well physical conditions in hospitals at grass roots level to city headquarters even. The bureaucratic and ineffective management systems failure to handle grievances and inability to revise job descriptions to suit the changing practices in the Bangladesh health sectors. This has the potential to create a feeling of violation of the employees' rights, leading to departmental action and turnover.

In this segment, the research question on what Human Resources practices are employed in managing performance in the Public Service has been answered. Likewise, the research objective set out to identify the HR practices and methods used in the Public Service to manage performance has also been met.

5.2. Objective Two (RO2): Determining the effectiveness of the performance management tools for measuring performance.

In the above section, the study focused on identifying the HR practices and methods used in the Public Service to manage performance. The following paragraphs will shed light on to determine the effectiveness of the performance management tools for measuring performance.

\subsubsection{Tools}

In Bangladesh Civil Service, the major tool used to manage performance of the civil servants is the ACR Form (Annual Confidential Report) or Special Confidential Report (for a shorter period of time) drawn from the immediate superior or reporting boss. It is closely linked to the strategic vision and mission of the concern division/ministry. The individual employee's yearly work plans are pre-reviewed at the commencement of each assessment period. The availability of this tool though providing comfort of the existence of an appropriate mechanism for evaluating employee and consequently overall organizational performance, does prompted the electorate to provide guarantees that it will measure performance unless the implementation is well managed. Performance management tool though has 
positive effect on organizational performance in literatures in the field of private (Nayaab et al., 2011; Osman et al., 2011) and public organizations (Barney, 1995), however, our study denotes the opposite. It might be due to have been used obsolete tool which is in disjunction with the objectives of the organizational performance.

\subsubsection{Review and measurement}

At the outset it must be posited that the ACR instrument on its own cannot suffice for managing performance solely as it is just one of the tools available. It needs to be integrated with other modern support systems that aim at improving overall organizational performance such as $360^{\circ}$ feedback and upward feedback in order to give a comprehensive and well-rounded assessment. Even in making year plans and setting targets, the organization needs to be satisfied that the levels of competency of the employees are those required to meet the expectations of the job and the behavior that will influence the job holder to perform in the required manner. It should, therefore, be borne in mind that having the qualified and competent employees who do not possess the appropriate and desired job behaviors will not result in good performance and consequently the organizations will be supposed to face fail. The performance measurement tool be employed must, therefore, not only to measure the physical attributes of job performance but also the intangible ones that reflect on how well the job is done. The goal of the Public Service performance is to be managed efficiently and effectively. As public is more concerned to see the service delivery with cost cutting/cost reduction philosophy without compromising with the quality of the service.

It is expected that the Public Service should strive to ensure a prominent stand in the market in respect of producing innovative products and services as they are believed to possess a robust systems at their disposal. The tool that the Public Service uses to measure performance should, therefore, not only focus on the results of the work done in terms of completion of tasks but also review the methods used so that it generates much appreciated service or product to the general mass. For similarly reason, researchers suggest that organizations should not focus on fulfilling one objective only rather ensure that the organization should achieve its main objective to be the market leader in that more customers are attracted through their innovative product and services. Such innovation should involve the prudent use of resources available in the organization to ensure that costs are kept to the minimum and generally productivity is enhanced. It is expected that if employees are working well, they will be applying the required positive 
behaviors from which others may learn and ultimately these will help the organization reposition itself in order to serve the public interest better. An interviewee (education sector executive) opined that perhaps if the appraisals were regular and used to assess the training needs, then tailor made training could have been useful in overcoming the lack of performance. Dhakal and Nawaz (2009) opined that human capital to be developed for capacity building, however, they are still left behind. It is proposed that HRM practice effectively can make the workforce as a source of competitive advantage (Hassin, 2009), if functionally flexible HR systems are established in conjunction with differentiation strategies (Onyango, Monica, Edwin, \& Roselyne, 2009).

\subsubsection{Best HR practice}

This study noted that recruitment and selection, training and development, motivation, engagement, performance appraisal and feedback, and employee compensation among other practices play a critical role in ensuring the best employee performance to the desired level of organizational expectations (Gould-Williams, 2003; Hoque et al., 2018; Khan \& Ali, 2014; Nayaab et al., 2011; Osman et al., 2011). It is indispensable to examine these practices in light of their effects on Performance Management especially in Public Service organizations (Jacobs, 2009). The results of the study showed that most of the employees are aware of the strategic objectives of the Public Service organization they serve $(85.8 \%)$ and also that the work they do is tailored to meet the organizational objectives $(83.7 \%)$. Most of these employees we could assume were recruited through a rigorous selection process of three distinctive phases (preliminary test, written test, and final viva) by the responsible Public Service Commissions (PSC), and therefore, possessed the qualifications that were sought at recruitment. Although, the findings depicted that most of the employees $(85.8 \%)$ were suitably qualified for the jobs and were contributing to the overall objective of the organization $(81.8 \%)$, however, it was found that the employee performance feedback (56.7\%) and employee compensation (50.2\%) were almost average. These statistics were inadequate and more needed to be done to enhance the sense of equity and providing appropriate performance feedback philosophy and mechanisms. Perhaps as suggested above, the use of an integrated system of performance management tools would be able to compensate for existing gaps. Strands of researchers (Bass \& Avolio, 1994; Uddin \& Khan, 2017) suggested that "managers ought to give direction, set up jobs and provide for the development of future leaders. However, this is possible if the supervisors and employees are working together and coordinating on a variety of tasks given". In this study, evidence shows a lack of involvement 
and interest in subordinate's work (72\%) which indicates a Leader-Member-Exchange gap of $28 \%$ which could be a source of failure for the organization. It is noteworthy that this could be the main constraint in producing future leader to come into action in the coming days. The research also demonstrated that the supervisors did not take any interest in employee's personal life (49\%), also accounts for the lack of interest in the career development of the employees (65\%). Even though, the employees have the appropriate skills and equipment to perform well in their current jobs, and continually seek to develop their potential to help them fit for future of the organization through a well-designed training and development programs.

The study findings further evidence that the employees generally are committed to doing their level best and produce quality work $(73.8 \%)$ within an ideal work environment in which they could excel in (69.8\%). Even though, these may not be the jobs they had dreamed for $(52.9 \%)$ as circumstances during scarcity of jobs compelled the employees to get into the first available job with a hope that in course of time they would grow to like it. This aspect is also critical for supervisors as they guide employees on their career paths to help them not only grow but also develop liking and positive attributes towards their job.

The results exposed that only two HR practices are aimed at producing positive results (one is not significant predictor even) in the work place that contribute to the attainment of organizational objectives. The implementation of these practices and the organizational culture will determine how effective these practices will be in influencing performance management. Well-implemented HR practices will help the organization to align employees' goals with those of the organization, so that as they strive to achieve personal goals as well as to improve organizational performance. In addition, supervisors will notice on their employees' performance gaps and help to identify strengths to further enhance employee competences and reduce the weaknesses.

When HR practices are successfully employed in the Public Service, it is expected that employees will develop a sense of belongingness and responsibility for achieving the targeted results, which should immediately be acknowledged and rewarded. This could transform employees to be more motivated, committed and engaged which provide a good standing of the organization for higher productivity and higher retention levels of staff. When employees are engaged, the citizenship behavior will be prominent among them to be more productive, efficient and therefore, reduce costs-related wastages by duplication of activities. 
Indeed as already alluded to, the training and development programs for employees are cardinal as their soft skills and behaviors that constitute the talent pool the organization has, will help to differentiate and gain competitive advantage over the competitors. If the organization is to achieve positive results from its HR practices, it should support the best practices of performance management as well as talent management that embodies behaviors, skills and attitudes that will help the organization succeed and ensure that these are inculcated in their employees.

In an attempt to answer the research question of what the effects of HR practices are on performance managements, the following are noteworthy:

a. The organization will be able to identify performance gap and subsequently determine the appropriate rewards systems or corrective remedial measures.

b. Judicious alignment between employee goals and organization's goals or its failure helps to identify gaps and minimize the differences that the objectives are achieved with minimum loss of resources.

c. The available performance data should help management in making quality decisions relating to employee performance management to improve performance and productivity.

However, in closing the discussion, the findings of this study are summarized in the Table 5 below;

Table 5: Summary of key findings of the study

\begin{tabular}{|c|c|c|}
\hline & Research Objectives & Major activities derived \\
\hline$\overline{1}$ & $\begin{array}{l}\text { Identifying the HR practices and } \\
\text { methods used in the Bangladesh } \\
\text { Civil Service (BCS) to manage } \\
\text { performance. }\end{array}$ & $\begin{array}{l}\text { 1. Managing employee and organizational } \\
\text { performance } \\
\text { 2. Performance evaluation and feedback } \\
\text { 3. Compensation and benefits } \\
\text { 4. Training and development } \\
\text { 5. Recruitment, selection and placement } \\
\text { 6. Leadership }\end{array}$ \\
\hline 2 & $\begin{array}{l}\text { Determining the effectiveness of the } \\
\text { performance management tools for } \\
\text { measuring performance. }\end{array}$ & $\begin{array}{l}\text { 1. Tools } \\
\text { 2. Review and measurement } \\
\text { 3. Best HR practice }\end{array}$ \\
\hline
\end{tabular}

\section{Recapitulation and policy implications}

At the end of the study, it is important to refocus on the research questions and objectives that guided this research. A brief summary of the conclusions drawn from each of the research objectives is, therefore, presented. This study conducted to seek answers to the research objectives covering both employees and management perspectives were generated as indicated below; 
The research objectives were satisfied after careful analysis of the results have been drawn from one hundred and forty two (142) employee and seven (7) executive (or direct level) as respondents for the interviews. In attempting to meet these objectives, the study also sought to establish the significant contribution to the human resource practices that make to employee retention for steady development. The search for answers to the research questions has unraveled a number of issues especially from the employee perspective in a service oriented public service organization (Education and Health) where public expectations and perceptions of quality of service delivery are varied. This further buttresses the strong belief that HR practices can only be ignored by practitioners to their own loss as organizations need to retain appropriate skills to perform and meet their mandates.

With regard to RO1, it has been noted from the mixed method study conducted through survey and interviews that among the best practice standard of HR practices, recruitment, selection and placement, training and development, employee compensation and benefits, employee performance management, performance evaluation feedback, and the leadership philosophy in the organization remain prominent. Organizations that implement these HR practices appropriately, can expect to achieve higher profits with higher levels of efficiency. However, the starting point is the nature and type of persons that are recruited because their characteristics will predispose them to perform, if they are placed in right job with expected higher retention probability, it would help the organization not only recoup costs of investments in their development but also maintain the expertise necessary to create competitive advantage over their competitors.

In respect of $\mathrm{RO} 2$, it is discovered that there are conventional performance management tools such as ACR Form in use though on their own appear inadequate and need to be complemented by other alternative tools. The $360^{\circ}$ feedback system and balanced scorecard tool, in course of time, has gained popularity among progressive organizations and deserves consideration. Further, even where the tools for managing and measuring performance do exist, it is important to maintain the standard and integrity of the HR practices so that the tools are used to measure and manage what they ought to.

This study has revealed some important impacts of HR practices create such as increased employee recognition, career growth and commitment. Further, if the impact is positive, then higher retention levels will be expected. In this state, it is expected that levels of motivation and productivity will also be correspondingly high which will please both employees and employers and create peace and harmony in the organization 
that enhances greater employee performance. When employees' work and contribution are appreciated and valued by their coworkers, this will create fellow feelings among each other for the welfare and benefit of the coworker which believed to create organizational citizenship behavior.

Hence, this study, from the noticeable differences in results, has important implications for the policy makers and practitioners of BCS organization. In findings, no simple answer exists to the question of which specific HR practice stimulate performance management of public service. Practical implications for policy makers are that they should enhance motivation, compensation, and before implementing HRM practices should take into account universal HR practices as well as sector-specific conditions.

\section{Conclusion}

In a workplace the human beings should be dealt with special care and should not be taken as insignificant and left to chance. All Directors and other executives at various levels perform HR functions with implications for HR practices. Therefore, the application of HR practices should be formalized and allowed to permeate all levels of the organization. The organizations should endeavor to eliminate or minimize all manner of self-induced human nature problems that may affect performance management in the organization. Further, all impediments that tend to reduce employee interest and commitment to the organization also need to be overcome. Workers should not be considered as the only vehicle of production or output rather recognized as partners in the provision of a service or product that is desired by customers. The gap between management and employees should be reduced considerably to improve communication and avoid creating positions of them (executives) and us (employees) which predisposes a confrontational stance even when it is unnecessary.

This study is limited to and focused on HR practices used in Bangladesh Civil Services (BCS), such as health and education sector only for performance management. Since, the research was limited to only two Ministries of Government, perhaps further research in the same area could be undertaken in other Government agencies or look at the specific HR practices within the same department. Other potential moderating factors can be tested for possible relationships between HR practices and organizational performance as appeared in previous studies (Kooij, Jansen, Dikkers, \& De Lange, 2010; Rabl, Jayasinghe, Gerhart, \& Kuhlmann, 2014; Subramony, 2009). Further, it may be useful to test the Balanced Scorecard tool in managing performance in the Public Services. Within the time available, therefore, this research could only cover what has been reported 
upon, hence, great chance and potential are still left for investigation in future intervention.

\section{References}

Amani, S. (2013). The impact of human resource management practices on employees' performance: A study of public sector in Babrain. Paper presented at the IIAS-IASIA Joint Congress, 2013. Retrieved August 26, 2019 from, https://www.researchgate. net/publication/263621065

Armstrong, M., \& Murlis, H. (2007). Reward management: a handbook of remuneration strategy and practice. Kogan: Page Publishers.

Andaleeb, S. S. (2001). Service quality perceptions and patient satisfaction: a study of hospitals in a developing country. Social Science \& Medicine, 52(9), 1359-1370.

Babbie, E. (2010). The practice of social research (12th ed.). Belmont: Wadsworth. Barney, J. (1995). Looking inside for competitive advantage. The Academy of Management Executive, 9(4), 49-61.

Barney, J. B. (1991). Firm resources and sustained competitive advantage. Journal of Management, 17(1), 99-120.

Bass, B. M., \& Avolio, B. J. (Eds.). (1994). Improving organizational effectiveness through transformational leadership. Sage.

Boxall, P., \& Purcell, J. (2011). Strategy \& HR Management (3rd ed.). New York: Palgrave Macmillan.

Brown, K. (2004). Human resource management in the public sector. Public Management Review, 6, 303-309. doi:10.1080/1471903042000256501

Budhwar, P. S., Chand, M., \& Katou, A. A. (2007). The impact of HRM practices on organisational performance in the Indian hotel industry. Employee relations.

Burke, R. J., Noblet, A. J., \& Cooper, C. L. (Eds.). (2013). Human resource management in the public sector. Cheltenham, UK: Edward Elgar Publishing.

CIMA. (2010). New public sector performance management making fiscal consolidation smarter, CIMA 2010 June, discussion paper.

Dhakal, T. N., \& Nawaz, F. (2009, December 11-13). Strategy for improving buman capital in Bangladesh and Nepal: Does it help for women empowerment. Paper presented at the Network of Asia-Pacific Schools and Institutes of Public Administration and Governance (NAPSIPAG), Annual Conference, Malaysia.

Dodani, S., \& LaPorte, R. E. (2005). Brain drain from developing countries: How can brain drain be converted into wisdom gain? Journal of the Royal Society of Medicine, 98(11), 487-491. 
Gould-Williams, J. (2003). The importance of HR practices and workplace trust in achieving superior performance: A study of public-sector organizations. International Journal of Human Resource Management, 14(1), 28-54.

Guest, D. E., Michie, J., Conway, N., \& Sheehan, M. (2003). Human resource management and corporate performance in the UK. British Journal of Industrial Relations, 41(2), 291-314.

Hassin, A. (2009). The link between operations strategy and human resource management for NGOs working in unstable environments. Journal of Business Systems, Governance and Ethics, 4(3), 44-46.

Hoque, A. S. M. M., Awang, Z., Siddiqui, B. A., \& Sabiu, M. S. (2018). Role of employee engagement on compensation system and employee performance relationship among telecommunication service providers in Bangladesh. International Journal of Human Resource Studies, 8(3), 19-37.

Hussain, M. T., \& Utsho, M. I. (2018). Measuring the casual relationship between the HRM practices and organizational performance in selected commercial banks in Bangladesh. International Journal of Advanced Multidisciplinary Scientific Research, 1, 34-42.

Iyer, D. (2011). Tying performance management to service delivery: Public sector reform in Malaysia, 2009-2011. Innovations for Successful Societies, Princeton University. Retrieved May 2, 2017, from http:/ / www.princeton.edu/successfulsocieties

Jacobs, C. (2009). How to bring about change in the Bangladesh civil service? Attempts to change mindsets, behaviours and practice. Public Administration and Development: The International Journal of Management Research and Practice, 29(3), 218-227.

Joarder, T., Rawal, L. B., Ahmed, S. M., Uddin, A., \& Evan, T. G. (2018). Retaining doctors in rural Bangladesh: A policy analysis. International Journal of Health Policy and Management, 7(9), 847-858. doi: 10.15171/ijhpm.2018.37

Joseph, K. E., \& Dai, C. (2009). HRM practices and organisational performance: An empirical analysis. International Journal of Business and Management, 4(8), 117-127.

Juhdi, N., Pa'wan, F., \& Hansaram, R. M. K. (2013). HR practices and turnover intention: the mediating roles of organizational commitment and organizational engagement in a selected region in Malaysia. The International Journal of Human Resource Management, 24(15), 3002-3019. 
Khalid, M., Rehman, C. A., \& Ilyas, M. (2014). HRM practices and employee performance in public sector organizations in Pakistan: An empirical study. International Journal of Management Sciences and Business Research, 3(2), 69-81.

Khan, M. A., \& Ali, A. J. (2014). The role of training in reducing poverty: The case of the ultra-poor in Bangladesh. International Journal of Training and Development, 18(4), 271-281. doi: 10.1111/ijtd.12041

Khan, M. A., \& Ali, A. J. (2015). Do non-governmental organisations' socio-economic and training programmes improve disaster prevention capacity of their beneficiaries? International Social Work, 58(3), 401-420. doi: $10.1177 / 0020872815570074$

Khan, M. A., \& Jahur, M. S. (2007). Human resource development practices in some selected business enterprises in Bangladesh: An explanatory study. Indonesian Management and Accounting Research, 6(1), 16-32.

Khatri, N. (1999). Emerging issues in strategic HRM in Singapore. International Journal of Manpower, 20(8), 516-529.

Kooij, D. T. A. M., Jansen, P. G. W., Dikkers, J. S. E., \& De Lange, A. H. (2010). The influence of age on the associations between HR practices and both affective commitment and job satisfaction: A meta-analysis. Journal of Organizational Behavior, 31, 1111-1136. doi:10.1002/job.666

KPI Institute. (2013). Performance Management in 2013. Melbourne: KPI Institute.

Lado, A. A., \& Wilson, M. C. (1994). Human resource systems and sustained competitive advantage: A competency-based perspective. Academy of Management Review, 19(4), 699-727.

Lusale, D. (2007). Why do Zambia health workers migrate abroad? Bulletin von medicus mundi scheweiz, 104(5), 11-18.

Malhotra, N. K. (2007). Marketing research: An applied orientation (5th ed.). New York: Prentice Hall.

Mason, E. Y., \& Bramble, W. J. (1978). Understanding and conducting Research: Application in educational and behavioral sciences. New York: McGraw Hill.

Morgan, D. L., Ataie, J., Carder, P., \& Hoffman, K. (2013). Introducing dyadic interviews as a method for collecting qualitative data. Qualitative Health Research, 23(9), 1276-1284. doi: 10.1177/1049732313501889

Mostafa, A. M. S., \& Gould-Williams, J. S. (2014). Testing the mediation effect of person-organization fit on the relationship between high performance HR practices and employee outcomes in the Egyptian public sector. The International Journal of Human Resource Management, 25(2), 276-292. 
Nadiri, H., \& Tanova, C. (2010). An investigation of the role of justice in turnover intentions, job satisfaction, and organizational citizenship behavior in hospitality industry. International Journal of Hospitality Management, 29(1), 33-41.

Nayyab, H., Hamid, M., Naseer, F., \& Iqbal, M. (2011). The impact of HRM practices on the organizational performance. The study of banking sector in Okara, Punjab (Pakistan). Interdisciplinary Journal of Contemporary Research in Business, 3(3), 661-672.

Onyango, F. E., Monica, A., Edwin, O., \& Roselyne, O. (2009). The role of human resource systems and competitive strategies in hospitality organizational performance in Kenya. International Journal of Hospitality \& Tourism Administration, 10(2), 174-194. doi: 10.1080/15256480902851131

Orodho, A. J., \& Kombo, D. K. (2002). Research methods. Nairobi: Kenyatta University, Institute of Open Learning.

Osman, I., Ho, T. C., \& Carmen Galang, M. (2011). The relationship between human resource practices and firm performance: an empirical assessment of firms in Malaysia. Business Strategy Series, 12(1), 41-48.

Paauwe, J. (2004). HRM and performance: Achieving long-term viability. Oxford: Oxford University Press.

Paauwe, J. (2009). HRM and performance: Achievements, methodological issues and prospects. Journal of Management Studies, 46(1), 129-142.

Penrose, E. T. (1995). The theory of the growth of the firm. New York: Oxford University Press.

Rabl, T., Jayasinghe, M., Gerhart, B., \& Kuhlmann, T. M. (2014). A meta-analysis of country differences in the high-performance work system-business performance relationship: The roles of national culture and managerial discretion. Journal of Applied Psychology, 99, 1011-1041. doi:10.1037/a0037712

Roch, C. H., \& Poister, T. H. (2006). Citizens, accountability, and service satisfaction: The influence of expectations. Urban Affairs Review, 41(3), 292-308.

Rondeau, K. V., \& Wagar, T. H. (2001). Impact of human resource management practices on nursing home performance. Health Services Management Research, 14(3), 192-202.

Rubel, M. R. B., \& Kee, D. M. H. (2014). Quality of work life and employee performance: Antecedent and outcome of job satisfaction in Partial Least Square (PLS). World Applied Sciences Journal, 31(4), 456-467. 
Rundle, S. J. (1997). Flexibility, adaptiveness and responsiveness (FAR-ness) as the key success factors in market entry in South East Asian growth wedge. Unpublished doctoral dissertation: Monash University, Victoria, Australia.

Schuler, R. S., \& Jackson S. E. (1987). Linking competitive strategies with human resources management practices. Academy of Management Executive, 1(3), 207-219.

Schuler, R. S., \& MacMillan, I. C. (1984). Gaining competitive advantage through human resource management practices. Human Resource Management, 23(3), 241-255.

Siddiquee, N. A. (2003). Human resource management in Bangladesh Civil Service: constraints and contradictions. International Journal of Public Administration, 26(1), 35-60. doi.org/10.1081/PAD-120018293

Storey, J. (1995). Human Resources Management: A critical Text. London: Routledge.

Subramony, M. (2009). A meta-analytic investigation of the relationship between HRM bundles and firm performance. Human Resource Management, 48, 745-768. doi:10.1002/hrm.20315

Tzafrir, S. S., Harel, G. H., Yehuda, B., \& Dolan, S. M. (2004). The consequences of emerging HRM practices for employee trust in their managers. Review, 33(6), 628-647.

Uddin, M. M., \& Khan, M. A. (2017). Role of leadership on organizational learning at private universities of Bangladesh. IIUC Studies, 14(2), 9-34.

Uddin, M., Ali, K., \& Khan, M. A. (2018). Impact of service quality (SQ) on student satisfaction: empirical evidence in the higher education context of emerging economy. AL-'ABQARI: Journal of Islamic Social Sciences and Humanities, 16, 31-67.

van Veldhoven, M. (2005). Financial performance and the long-term link with HR practices, work climate and job stress. Human Resource Management Journal, 15(4), 30-53.

Wright, P. M., \& Snell, S. A. (1991). Toward an integrative view of strategic human resource management. Human Resource Management Review, 1(3), 203-225.

Wright, P. M., Gardner, T. M., Moynihan, L. M., \& Allen, M. R. (2005). The relationship between HR practices and firm performance: Examining causal order. Personnel Psychology, 58(2), 409-446.

Wright, P. M., MacMahan, G. C., \&MacWilliams, A. (1994). Human Resources and Sustained Competitive advantage: A resource based perspective. International Journal of Human Resource Management, 5(2), 301-326. 
Yin, R. K. (2012). Application of case study research (3rd ed.). California: Sage.

Zikmund, G. K., Babin, B. J., Carr, J. C., \& Griffin, M. (2013). Business Research Methods (9th Edition). Cengage Learning: South Western.

\section{Corresponding author}

Mohammad Aktaruzzaman Khan can be contacted at: rajarkul2002@yahoo.com 